\title{
PROSES MANJEMEN, STRUKTUR FORMAL DAN PENGGUNAAN INFORMASI
}

\author{
Meutia \\ Universitas Sultan Ageng Tirtayasa \\ tia-almer@yahoo.co.id
}

\begin{abstract}
Abstrac: The purpose of this paper is to research whether activity of strategy development and implementation used in practice are formal structured processes, and whether financial and non-financial information are of equal importance across strategy development and implementation activities. This study uses senior accounting officers within large Banten and West Java firms (those employing more than 250 employees). The result from hypotheses testing showed that that strategy development and implementation were relatively formally structured processes in the companies investigated. Nevertheless, financial information and non-financial information are considered equally important both for the development of the strategy and implementation of strategies for the companies surveyed. Companies, it provides value and weight as important both to the financial information for strategy implementation process.
\end{abstract}

Keyword: Strategy mangement processes, formal structured porcesses, financial and non financial information

\begin{abstract}
Abstrak: Tujuan dari makalah ini adalah untuk meneliti apakah aktivitas perkembangan strategi dan implementasi yang digunakan dalam praktek operasional di perusahaan adalah bentuk proses yang terstruktur secara resmi, dan apakah informasi finansial dan informasi non finansial memiliki nilai yang sama pentingnya baik untuk aktivitas implementasi maupun untuk aktivitas perkembangan strategi. Survei dilakukan untuk mengumpulkan semua data yang diperlukan dalam studi ini dengan menggunakan kuesioner terstruktur yang didistribusikan. Populasi yang menjadi target penelitian terdiri dari para pejabat akuntansi senior dalam perusahan-perusahaan yang berkedudukan di Banten dan Jawa Barat berukuran besar (yang mempekerjakan lebih dari 250 pegawai). Hasil akhir statistik yang diperoleh memberikan konfirmasi bahwa aktivitas dan proses perkembangan strategi serta implementasinya secara relatif merupakan sebuah proses terstruktur dalam perusahaan yang diteliti. Meskipun demikian, informasi finansial dan informasi non finansial dianggap sama pentingnya baik untuk proses perkembangan strategi maupun implementasi strategi bagi perusahaan-perusahaan yang disurvei. Perusahaan-perusahan tersebut memberikan nilai yang dan bobot yang sama pentingnya baik terhadap informasi finansial untuk proses implementasi strategi.
\end{abstract}

Kata kunci: proses manajemen strategi, proses struktur formal, informasi keuangan dan informasi non keuangan

\section{PENDAHULUAN}

Untuk menilai peranan informasi dalam melakukan aktivitas strategis sebuah perusahaan, maka sangatlah perlu bagi kita untuk mempertimbangkan perbedaan yang 
terdapat antara pendapat normatif dan pendapat yang bersifat preskriptif (deskriptif) berkaitan dengan strategi yang ditemukan dalam literature akuntansi manajemen.

Literature mengenai preskriptif strategi, strategi dipertimbangkan sebagai sebuah pernyataan yang terbentuk secara resmi dari tujuan atau rencana perusahaan guna mengidentifikasi sasaran dan tindakan yang akan dilakukan oleh perusahaan tersebut. Perusahaan diasumsikan akan mengikatkan diri mereka pada penentuan pilihan yang bersifat strategis dengan cara yang ekonomis meski terdapat batasan informasi, bias kognitif yang mungkin muncul dan ambiguitas kausal (Amit dan Schoemaker, 1993). Strategi dilihat sebagai sebuah rencana yang diidentifikasi secara sadar, bersifat proaktif dan dibentuk sebelum sebuah keputusan diambil serta tindakan dilakukan (Ismail dan Ghozali, 2015).

Porter (1985) sebagai contohnya, memandang strategi sebagai perusahaan memposisikan dirinya dalam lingkungan bersaing dan menyatakan bahwa pembentukan strategi adalah sebuah keunggulan bersaing yang berkelanjutan. Ia mengembangkan beberapa alat strategis (lima upaya analisa industri, analisa rantai nilai, dan konsep mengenai strategi umum) untuk menganalisa dan menentukan posisi perusahaan dalam pasar bersaing. Porter (1985) juga memberikan argumentasi bahwa sebuah perusahaan sebaiknya membangun keunggulan bersaing yang berkelanjutan, memilih posisi strategis, mengembangkan aktivitas yang unik dan menentukan bagaimana mereka dapat masuk dalam aktivitas pemberian nilai tambah pada rantai nilai perusahaan (Porter, 2001).

Peneliti lainnya menggambarkan bagaimana keunggulan bersaing perusahaan didasarkan pada sumber daya strategis, asset dan kapabilitas yang dimiliki oleh perusahaan (Breckova dan Havlick, 2013). Pemikiran strategis yang mendasari kecenderungan ekonomis ini berkaitan dengan keputusan untuk mendistribusikan sumber daya, tindakan organisasional yang akan dilakukan serta hasil akhir yang menjadi tujuan perusahaan (Havlick et al., 2013).

Konsep preskriptif dari strategi menggunakan sistem informasi manajemen formal. Pencapaian tujuan perusahaan ini memerlukan analisa data yang akan memberikan umpan balik pada proses pengambilan keputusan. Jika pengambilan keputusan strategis adalah sebuah perilaku yang terstruktur dan terencana dengan baik, maka hal ini akan menarik sejumlah informasi yang telah dipersiapkan secara formal untuk mengidentifikasi peluang internal dan eksternal serta ancaman yang mungkin muncul tanpa mengabaikan kemungkinan inovasi strategis (Schoemaker dan Amit, 1994). Mereka mengasumsikan bahwa pihak manajer secara resmi akan menganlisa upaya bersaing dan akan menilai dengan penuh kesadaran alokasi sumber daya yang terjadi dalam perusahaan berikut penggunaannya sebagai bagian dari perkembangan strategi. Implementasi strategi ini akan melibatkan analisa yang sifatnya ekstensif dari informasi yang bersifat ekonomis, kuantitatif dan kualitatif. Pada akhirnya, upaya pencapaian keunggulan bersaing yang berkelanjutan dilihat sebagai jalan keluar dari pilihan manajerial yang bersifat diskresi dan akumulasi sumber daya yang bersifat strategis serta pendayagunaan sumber daya tersebut, dimana hal ini semua tergantung pada hasil akhir dan penggunaan sistem informasi manajemen yang telah didesain secara efektif (Grant, 1996).

Sebaliknya, sudut pandang deskriptif mengenai strategi adalah peranan untuk melakukan interaksi antara manajemen, pegawai dan lingkungan dimana proses strategis yang ada dianggap bersifat kompleks dan eksis dalam keadaan tidak stabil yang bersifat kontinyu dengan konsekuensi yang kadangkala muncul dari tujuan yang telah direncanakan dari awal. Strategi dianggap sebagai pandangan yang didasarkan secara 
organisatoris, dengan pengambilan keputusan serta implementasinya yang bersifat kompleks, dinamis dan memiliki beragam sisi (Hamel dan Prahalad, 1994).

Aktivitas organisatoris dilakukan untuk dibentuk dari beragam kepentingan termasuk upaya khusus perusahaan dan juga munculnya tekanan institusional (Quin, 1980). Strategi tidak sepenuhnya dipandang sebagai suatu hal yang dikembangkan dari atasan untuk kemudian disalurkan ke bawahan ataupun sebagai pola tindakan baru yang dianggap akan muncul akibat perilaku yang beragam. Strategi sebagian besar muncul melalui akar dari proses pengambilan keputusan (Mintzberg dan McHugh, 1995). Tugas untuk manajer dalam perspektif ini adalah menciptakan konteks untuk pembentukan strategi dan untuk mendeteksi pola yang muncul untuk kemudian membantu mereka dalam membentuk strategi. Keseimbangan dicapai antara pemikiran tindakan, pembelajaran dan pengendalian, dan stabilitas serta perubahan. Sumber informasi yang ada sangatlah beragam dan tidak sepenuhnya berasal dari sistem yang telah terbentuk secara resmi. Komunikasi yang berisi informasi ini akan mempengaruhi proses strategis dengan cara yang tidak seragam. Bentuk serta pertukaran informasi yang terjadi bersifat sangat tidak terstruktur (Goold dan Quinn, 1990).

\section{KAJIAN TEORI}

Literature manajemen strategi memiliki pendekatan yang bebeda-beda dari sebuah proses pengambilan keputusan, hasil tulisan tentang aspek strategis dari ilmu akuntansi cenderung mengadopsi sudut pandang dari satu sisi semata.

Artikel yang membahas tentang ikatan dan hubungan yang terjadi antara sistem akuntansi manajemen dan manajemen strategi yang relatif bersifat baru dan muncul di tahun 1980an (Ismail, 2016). Sementara itu tinjauan mengenai literatur strategi akuntansi sudah dijelaskan oleh berbagai peneliti (Chenhall, 2005). Tujuan artikel ini adalah untuk mempertimbangkan dasar konseptual dimana strategi yang ada berhubungan dengan sistem akuntansi.

Beberapa peneliti percaya bahwa hubungan yang terjadi antara pengambilan keputusan strategis dan praktek akuntansi akan dipahami sebagai bentuk tindakan reflektif dari kompleksitas atau kerumitan yang terdapat dalam ketidakpastian organisatoris dan proses sosial yang menentukan hubungan antara pengambilan keputusan strategis dan praktek akuntansi (Thalassinos et al., 2013). Aktivitas pegambilan keputusan dan tindakan manajerial yang dilakukan oleh perusahaan dilihat sebagai bentuk yang bersifat dinamis dengan beragam tingkatan dan kekhususan dalam hal konteks dan bukannya bentuk yang terstruktur, terencana dan berkelanjutan yang telah tertata dengan baik (Bhimani dan Langfield-Smith, 2007).

Meskipun demikian sebagian besar literatur akuntansi yang membahas aspek strategis dari akuntansi, atau yang disebut dengan Akuntansi Manajemen Strategis (Strategic Management Accounting atau SMA), berkaitan dengan strategi dalam istilah deterministis dan rasionalistis dan dapat menjelaskan preskripsi akuntansi yang didesain serta dibentuk untuk mendukung tindakan strategis perusahaan (Kaplan dan Norton, 2004). Dalam literatur SMA, perkembangan dan implementasi strategi dipandang sebagai upaya resmi dimana praktek akuntansi manajemen berorientasi strategis dapat memberikan kontribusi besar terhadap perusahaan (Bhimani dan Langfield-Smith, 2007).

Fokus atau pusat perhatian dari penggunaan informasi ini (Brouthers dan Roozen, 1999) adalah adanya pra asumsi yang menyatakan bahwa informasi non finansial 
sangatlah diperlukan untuk menangkap relevansi keputusan dari pilihan strategis yang mengiringi terbentuknya analisa informasi finansial. Terdapat sejumlah studi yang memberikan indikasi bahwa para pejabat akuntansi senior dalam perusahaan memainkan peranan penting dan terus mengalami peningkatan dalam perolehan hak istimewa yang digunakan untuk proses pengambilan keputusan strategis (Bhimani dan Keshtvars, 1999), sehingga para pejabat akuntan senior tersebut akan terus menerus terlibat dan terikat dengan aktivitas strategis yang dilakukan oleh perusahaan (Guilding et al., 2000; Guilding dan McManus, 2002).

Palmer (1992) menjelaskan bahwa tugas menyatukan sistem SMA ke dalam proses manajemen strategis memberikan tanggung jawab besar terhadap para akuntan manajemen untuk mengidentifikasi orientasi strategis perusahaan dan untuk mempersiapkan informasi yang diperlukan oleh perusahaan bagi pengambilan keputusan. Simmonds (1982) mendukung sudut pandang yang menjelaskan bahwa SMA sebaiknya terus berusaha mencari dan meningkatkan informasi akuntansi manajemen yang berhubungan dengan faktor-faktor semacam posisi bersaing, penetapan harga, biaya dan volume. Ilmu pengetahuan tentang perusahaan pesaing dipertimbangkan dan dianggap dapat membantu pengambilan keputusan manajerial dengan tetap memperhitungkan respon yang mungkin muncul dari perusahaan pesaing.

Shank dan Govindrajan (1992) juga menarik kesimpulan berdasarkan kerangka kerja milik Porter tentang analisa rantai nilai dan analisa keunggulan bersaing untuk membantu dan mendukung analisa data biaya guna mengembangkan strategi yang unggul yang memungkinkan perusahaan dalam mencapai keunggulan bersaing yang berkelanjutan. Shank (1996) lebih lanjut memperlihatkan perilaku dari aspek manajemen biaya strategis yang memerlukan informasi penghubung antara data finanasial dan data non finansial yang memungkinkan perusahaan untuk mendapatkan pemahaman dan penilaian yang seimbang dari keutamaan strategi. Akhirnya, Bushman (2007) memberikan argumentasi bahwa akuntan manajemen menggunakan informasi finansial dan non finansial untuk mendukung pengambilan keputusan strategis.

Ringkasnya, literatur SMA preskriptif memberikan asumsi bahwa aktivitas strategis sebgaian besar bersifat formal dan terstruktur dan sudah mendukung keseimbangan penggunaan informasi finansial dan informasi non finansial dalam perkembangan serta implementasi strategi. Pendekatan pengambilan keputusan strategis ini menyatakan bahwa sudut pandang perkembangan strategi dan implementasinya adalah perubahan yang sifatnya mendesak, tidak terstruktur dan akan terus mengalami perubahan dimana perubahan ini akan dipadukan secara selektif dalam literatur SMA (Bhimani dan Langfield-Smith, 2007). Pertanyaan untuk investigasi atau penelitian ini adalah apakah aktivitas perkembangan dan implementasi dari strategi dalam prakteknya berbentuk terstruktur dan resmi, dan apakah informasi finansial dan informasi non finansial memiliki nilai yang sama pentingnya antara perkembangan strategi dan aktivitas implementasinya. Untuk melakukan penilaian secara empiris, maka kami membentuk hipotesa sebagai berikut:

H1: Perkembangan strategi dan implementasinya cenderung berbentuk resmi, terstruktur, dan bukannya sesuatu yang bersifat tidak resmi dan tidak terstruktur.

$\mathrm{H} 2$ : Informasi finansial sama pentingnya dengan informasi non finansial dalam perkembangan strategi.

H3: Informasi finansial sama pentingnya dengan informasi non finansial dalam implementasi strategi. 


\section{METODE}

Survei dilakukan untuk mengumpulkan semua data yang diperlukan dalam studi ini dengan menggunakan kuesioner terstruktur yang didistribusikan. Populasi yang menjadi target penelitian terdiri dari para pejabat akuntansi senior dalam perusahan-perusahaan yang berkedudukan di Banten dan Jawa Barat berukuran besar (yang mempekerjakan lebih dari 250 pegawai). Untuk mencapai ukuran sampel yang memadai dan melakukan generalisasi hasil akhir dari sampel awal yang dikumpulkan untuk studi ini, maka total populasi yang telah terkumpul terdiri dari 587 perusahaan Banten dan Jawa Barat berukuran besar. Keterbatasan ukuran terjadi karena perusahaan berukuran kecil dan menengah memiliki kesulitan tersendiri dan perusahaan-perusahan ini sebagian besar tidak memiliki akuntansi manajemen dan akuntansi strategis yang tepat (Chenhall dan Langfield-Smith, 1998).

Pengujian awal yang dilakukan adalah validitas konten (Zikmund, 2003). Instrumen penelitian akan diuji terlebih dahulu dan melalui pembahasan yang mendalam dengan pihak akademisi dan profesional di bidang akuntansi manajemen. Sebanyak lima pejabat akuntansi senior dan enam pihak akademisi berpartisipasi dalam proses pengujian awal. Untuk memastikan bahwa pejabat akuntansi senior dari sampel perusahaan yang ada bersedia untuk melengkapi dan mengisi kuesioner. Selain itu, untuk memaksimalkan tingkat respon, maka dua asisten peneliti diperbantukan selama 2 minggu untuk melakukan panggilan telepon kepada 587 perusahaan tersebut.

Hal yang perlu diperhatikan adalah adanya keterbatasan waktu atau pertimbangan masalah privasi perusahaan, sehingga pejabat akuntan senior dari perusahaan-perusahaan tersebut banyak yang menolak untuk berpartisipasi. Sebanyak 229 perusahaan menyatakan bahwa hal ini bertentangan dengan kebijakan mereka jika mereka merespon terhadap pertanyaan penelitian yang diajukan. Kuesioner yang dikirimkan hanya mendapat repson dari 288 pejabat akuntan senior yang setuju untuk berpartisipasi dalam survei tersebut (baik melalui pos ataupun e-mail tergantung pada preferensi). Sebuah surat yang menjelaskan tujuan penelitian dilampirkan dan amplop dengan prangko balasan juga disertakan ke dalam kuesioner yang dibagikan. Surat lanjutan akan dikirimkan tiga minggu kemudian setelah pengeposan kuesioner awal.

Terdapat 193 kuesioner yang dikembalikan, sehingga memberikan tingkat respon sebesar 67.01 persen. Dari ini semua, lima kuesioner tidak disertakan kerena tidak diisi secara lengkap. Sehingga tersisa sebanyak 188 kuesioner yang tetap dipertahankan untuk analisa lebih lanjut (dengan tingkat respon sebesar 65,27 persen).

Pada umumnya, peneliti hanya bekerja dengan tingkat kepastian sebesar 95\%. Ini artinya populasi total yang ada sebanyak 587 perusahaan dengan jumlah sampel minimum sekitar 220 dan bukannya 193 perusahaan (Saunders et al., 2000, p. 156). Meskipun ukuran sampel yang ada jauh lebih kecil, dan ini dianggap sebagai salah satu dari kelemahan penelitian, namun jumlah sampel ini tetap kami pertahankan dengan dasar pernyataan dari Shelby Hunt yang mengatakan bahwa bias non respon tidak terdiri dari aturan mendasar yang serta merta akan menolak hasil survei yang ada, kecuali terdapat perbebedaan yang benar-benar serius antara responden dan non responden, yang akan mengakibatkan hasil akhir penelitian tidak dapat dihandalkan (Hunt, 1990).

Untuk menguji apakah responden penelitian kami berbeda dengan non responden, maka kami meneliti apakah terdapat perbedaaan dalam nilai rata-rata untuk seluruh variabel yang digunakan dalam studi ini antara responden awal dan responden akhir. Alasan yang menjadi dasar analisanya adalah bahwa responden akhir (contohnya 
perusahaan sampel yang mengisi kuesioner yang diposkan untuk kedua kalinya) akan bersifat sama dengan populasi yang digunakan dalam penelitian, dibandingkan responden awal. Tidak ada perbedaan statistik yang signifikan yang ditemukan dalam studi ini, sehingga memberikan penjelasan bahwa bias non respon bukanlah masalah serius dalam studi ini.

Kuesioner survei terdiri dari tiga bagian: Bagian kesatu mengukur pentingnya formalitas terstruktur dalam proses pengambilan keputusan. Responden penelitian diminta memberikan indikasi pentingnya (dan formalitas) yang mereka berikan untk masingmasing aktivitas yang diukur secara terpisah dalam dua proses pengambilan keputusan strategis. Sebanyak empat item untuk mengukur pentingnya (dan formalitas) dari proses perkembangan strategi (dikembangkan dari penelitian milik Boyd dan Reuning-Elliot (1998) tentang formalitas dalam perencanaan strategis) dan lima formalitas dalam proses implementasi strategi (diadopsi dari Glaister et.al., 2008).

Bagian kedua terdiri dari tiga belas pertanyaan (item) yang berguna untuk mengukur pentingnya indikator finansial (sebanyak 5 item) dan indikator non finansial (sebanyak 8 item) yang digunakan sebagai informasi untuk perkembangan strategi dan implementasinya. Indikator finansial diadopsi dari Widener (2006) dan indikator non finansial dari Poincelot dan Wegmann (2006).

Pada kedua bagian tersebut skala Likert lima poin akan digunakan, dimana poin $1=$ tidak penting, poin $2=$ agak penting, poin $3=$ cukup penting, poin $4=$ penting dan poin 5 $=$ sangat penting. Dan akhirnya, di bagian ketiga terdapat pertanyaan tentang karakteristik demografis responden (contohnya, gender, usia, tingkat pendidikan, posisi dalam perusahaan, dan lain sebagainya).

Semua teknik dari analisa data multivariate umumnya memberikan asumsi distribusi normal. Dalam kasus kami semua item penelitian akan didistribusikan secara normal dan dapat diterima untuk analisa lebih lanjut karena secara respektif nilai kurtosis dan skewness kurang dari 2 dan 7 (West et al., 1995).

Terlebih lagi, sudah dikenal dengan baik bahwa dalam sebuah survei penelitian, jika survei tidak dilakukan dengan baik, maka akan memberikan hasil pengukuran yang salah dan hal ini menjadi salah satu sumber kesalahan yang paling signifikan dari munculnya bias penelitian. Meskipun demikian, kesalahan pengukuran hampir tidak pernah terelakkan. Kesalahan ini akan mempengaruhi hasil akhir dari penelitian yang menjadi fungsi dari upaya khusus (a priori) dan pengujian yang dilakukan (a posteriori), untuk meminimalkan dan menilai bias yang berpotensi terjadi. Berdasarkan validasi konstruk hal ini secara khusus dianggap relevan. Hal ini juga melibatkan proses multifaceted (beragam sisi) yang terdiri dari dua langkah mendasar. Langkah pertama adalah validitas konten yang memerlukan identifikasi kelompok item-item pengukuran yang dianggap bisa mewakili konstruk kepentingan penelitian.

Langkah kedua adalah validitas konstruk, yang berfungsi untuk membentuk indikator empiris guna mengukur konstruk sesungguhnya. Permasalahan ini dibahas mendalam pada Apendiks 1. Semua analisa (lihat Apendiks 1 untuk deskripsi lebih mendetail mengenai prosedur survei dan hasil akhir) memberikan kepastian yang cukup meyakinkan dimana pengukuran yang digunakan sudah valid dan dapat dihandalkan.

\section{HASIL DAN PEMBAHASAN}

Statitistik deskriptif. Tabel 1 memberikan dasar perhitungan statistik untuk faktor first order yaitu "Formalitas terstruktur dari proses perkembangan strategi", "Formalitas 
terstruktur dari proses implementasi strategi", "Pentingnya informasi finansial bagi proses perkembangan strategi", "Pentingnya informasi non finansial bagi proses perkembangan strategi", "Pentingnya informasi finansial bagi proses implementasi strategi", dan "Pentingnya informasi non finansial bagi proses implementasi strategi".

Seperti yang kita lihat, semua faktor dikarakterisasikan 'penting', karena nilai ratarata yang diperoleh jauh lebih besar daripada empat. Faktor terpenting adalah "Pentingnya informasi finansial bagi proses implementasi strategi" dengan nilai sebesar 4.53, sedangkan faktor yang dianggap tidak terlalu penting adalah "Pentingnya informasi finansial bagi proses perkembangan strategi" dengan nilai sebesar 4.11.

Tabel 1. Statistik deskriptif

\begin{tabular}{|c|c|c|c|c|c|}
\hline Factor & Mean & $\begin{array}{c}\text { Std. } \\
\text { Deviation }\end{array}$ & $\begin{array}{c}\text { Coefficient of } \\
\text { Variation }\end{array}$ & Median & Mode \\
\hline $\begin{array}{l}\text { Structured formality of the } \\
\text { strategic development process }\end{array}$ & 4.45 & 0.31 & 6.96 & 4.5 & 4.5 \\
\hline process & 4.43 & 0.33 & 7.44 & 4 & 4.4 \\
\hline $\begin{array}{l}\text { Importance of financial } \\
\text { information to strategic } \\
\text { development process }\end{array}$ & 4.11 & 0.73 & 17.76 & 4 & 4.2 \\
\hline $\begin{array}{l}\text { Importance of nonfinancial } \\
\text { information to strategic } \\
\text { development process }\end{array}$ & 4.16 & 0.48 & 11.53 & 4.12 & 4.13 \\
\hline $\begin{array}{l}\text { Importance of financial } \\
\text { information to strategic } \\
\text { implementation process }\end{array}$ & 4.53 & 0.27 & 5.96 & 4.6 & 4.4 \\
\hline $\begin{array}{l}\text { Importance of nonfinancial } \\
\text { information to strategic } \\
\text { implementation process }\end{array}$ & 4.36 & 0.27 & 6.19 & 4.37 & 4 \\
\hline
\end{tabular}

Koefisien untuk variasi yang terjadi dalam semua kasus kecuali, untuk variabel "Pentingnya informasi finansial bagi proses perkembangan strategi" bernilai kurang dari nilai pada titik potong sebesar $<15 \%$. Secara dekduktif, kami dapat mengatakan bahwa formalitas terstruktur dari dua proses pengambilan keputusan strategis, yaitu perkembangan strategi dan implementasinya adalah dua hal penting, yang artinya, hal ini sesuai dengan jawaban dari para responden. Reosponden menyatakan bahwa formalitas terstruktur akan selalu muncul dan ada dalam dua proses baik proses perkembangan strategi maupun proses implementasi strategi. Hal yang sama diaplikasikan untuk dua variabel lainnya, yaitu pentingnya informasi finansial dan informasi non finansial baik untuk proses perkembangan strategi maupun untuk proses implementasi strategi. Dengan kata lain, responden percaya bahwa informasi finansial dan informasi non finansial sangat penting untuk dua proses yang ada yaitu proses perkembangan strategi dan proses implementasi strategi.

Pengujian hipotesa penelitian. Berkaitan dengan hipotesa satu (H1), kami menyatakan bahwa Hipotesa 1 diterima. Hal ini berdasarkan pada hasil akhir yang diperoleh dan dijelaskan di Tabel 2. Karena dalam kedua kasus ini (formalitas terstruktur dari proses 
pekembangan dan implementasi strategi) memiliki nilai rata-rata (dari semua jawaban responden yang kami peroleh) berada diatas 4 (dimana skala Likert menyatakan bahwa poin 4 = penting). Secara analitis, untuk semua aktivitas yang terdiri dari proses perkembangan strategis, rat-rata memberikan indikasi pentingnya hal tersebut dengan nilai sebesar 4.45, sehingga sesuai dengan pernyataan formalitas terstrukur untuk aktivitas ini. Hal ini juga berlaku untuk semua aktivitas dari proses implementasi strategi, dengan nilai rata-rata sebesar 4.43. sehingga, jawaban dari semua responden dalam penelitian rata-rata memberikan hasil akhir kurang lebih sama untuk kedua proses manajemen strategi (baik proses perkembangan strategi dengan nilai sebesar 4.45 maupun proses implementasi strategi dengan nilai sebesar 4.43).

Untuk menguji pentingnya informasi finansial dan informasi non finansial dalam proses perkembangan dan implementasi strategi ( $\mathrm{H} 2$ dan $\mathrm{H} 3)$ maka analisa ANOVA digunakan dan untuk pengujian yang lebih spesifik maka digunakan uji sampel berpasangan (T-test). Dengan teknik ini, kami dapat membandingkan nilai pertengahan dari evaluasi antara informasi finansial dan informasi non finansial baik untuk Proses Perkembangan Strategi maupun untuk Proses Implementasi Strategi.

Tabel 2. Paired sample T-test

\begin{tabular}{lcccc}
\hline & Mean & Std. Deviation & $\mathrm{t}$ & Sig. (2 tailed) \\
\hline $\begin{array}{l}\text { Strategy development } \\
\text { Financial information }\end{array}$ & 4.16 & 0.53 & & \\
$\begin{array}{l}\text { Non Financial } \\
\text { information }\end{array}$ & 4.11 & 0.48 & -1.091 & 0.078 \\
$\begin{array}{l}\text { Strategy } \\
\text { implementation }\end{array}$ & 4.53 & 0.27 & & \\
$\begin{array}{l}\text { Financial information } \\
\text { Non Financial } \\
\text { information }\end{array}$ & 4.36 & 0.27 & 6.453 & 0.000 \\
\hline
\end{tabular}

Hasil akhir yang diperoleh dalam Tabel 2. mendukung H2, karena tidak ada perbedaan yang signifikan dan statistik antara kedua nilai rata-rata $(\operatorname{sig}=0.078>0.05)$ berkaitan dengan nilai dari informasi finansial dan informasi non fiannasial untuk perkembangan strategi. Dengan kata lain, tidak ada perbedaan yang signifikan yang ditemukan dalam variabel pentingnya informasi finanasial dan informasi non finansial untuk proses perkembangan strategi.

Sebaliknya, H3 ditolak karena terdapat perbedaan yang cukup signifikan dan statistik antara kedua nilai rata-rata berkaitan dengan pentingnya informasi finansial dan informasi non finansial untuk proses implementasi strategi. Nilai dari uji t secara statistik dinyatakan signifikan di tingkat $5 \%(\mathrm{sig}=0.000,0.05)$.

Informasi finansial yang muncul dari hasil akhir, jauh lebih penting dibandingkan informasi non finansial untuk kedua kasus yang ada (nilai mean adalah 4.16 vs 4.11 untuk proses perkembangan strategi dan 4.53 vs 4.36 untuk proses implementasi strategi). Selain itu, meskipun tidak dikemukakan, perlu diperhatikan bahwa pentingnya informasi finansial untuk impelementasi strategi memiliki nilai sebesar 4.53. Hal ini secara statistik menunjukkan bahwa informasi finansial untuk proses perkembangan strategi jauh lebih penting dibandingkan untuk proses perkembangan strategi (dengan nilai sebesar 4.16). 


\section{PENUTUP}

Simpulan. Tujuan dari makalah ini adalah untuk meneliti apakah aktivitas perkembangan strategi dan implementasi yang digunakan dalam praktek operasional di perusahaan adalah bentuk proses yang terstruktur secara resmi, dan apakah informasi finansial dan informasi non finansial memiliki nilai yang sama pentingnya baik untuk aktivitas implementasi maupun untuk aktivitas perkembangan strategi.

Hasil akhir statistik yang diperoleh memberikan konfirmasi bahwa aktivitas dan proses perkembangan strategi serta implementasinya secara relatif merupakan sebuah proses terstruktur dalam perusahaan yang diteliti. Meskipun demikian, informasi finansial dan informasi non finansial dianggap sama pentingnya baik untuk proses perkembangan strategi maupun implementasi strategi bagi perusahaan-perusahaan yang disurvei. Perusahaan-perusahan tersebut memberikan nilai yang dan bobot yang sama pentingnya baik terhadap informasi finansial untuk proses implementasi strategi.

Kecenderungan untuk lebih menggunakan proses yang terstrtuktur secara resmi mendukung perspektif rasional yang menjelaskan strategi, hal ini juga dijelaskan dalam literatur akuntansi manajemen. Meskipun demikian, hal ini menimbulkan argumentasi yang menyatakan bahwa formalitas mungkin secara umum akan berhubungan dengan perusahaan berdasarkan pada ukuran perusahaan yang dipilih untuk studi ini (hanya perusahaan yang berukuran besar). Hasil temuan yang diperoleh juga sebagian besar muncul dikarenakan partisipasi akuntan dalam proses strategi yang berhubungan pula dengan aspek perkembangan dan implementasi strategi yang lebih terstruktur.

Pendekatan dengan menggunakan balanced scorecard menekankan pada pentingnya untuk memadukan atau mengintegrasikan alat ukur informasi finansial dan non finansial dalam proses implementasi strategi (Kaplan dan Norton, 2004). Meskipun demikian, perusahaan-perusahaan yang disurvei di sini tampaknya lebih memberikan tekanan yang besar pada alat ukur yang bersifat finansial dalam proses implementasi strategi, tetapi bias yang muncul semacam ini tidak ditemukan pada proses perkembangan strategi. Penjelasan yang memungkinkan atas munculnya bias ini adalah bahwa informasi non finansial dianggap sama relevannya dengan konseptualisasi target strategis tetapi jika kita mengendalikan hal ini dan dengan terus menerus memonitor impelementasi strategi justru akan memberikan tekanan pada masalah finansial. Hal ini kemungkinan dikarenakan preferensi tradisional dari para akuntan, dimana para akuntan biasanya lebih memberikan nilai besar pada informasi finansial (Roslender, 1996). Hal ini juga berasal dari cabang dalam dunia akuntansi yang menyatakan bahwa akuntan cenderung lebih banyak berpartisipasi dalam proses implemetasi strategi dibandingkan proses perkembangan strategi, seperti yang telah dilaporkan dari berbagai survei (Guilding et al., 2000).

Pemahaman lebih lanjut terhadap hasil akhir ini mungkin akan muncul jika kita berusaha untuk mengidentifikasi perbedaan yang terjadi dari dua proses pengambilan keputusan strategi yaitu proses perkembangan strategi dan proses implementasi strategi yang merupakan cabang dari literatur manajemen strategi.

Menurut David (2010): Proses perkembangan strategi secara khusus merupakan proses intelektual yang berusaha untuk mengkonseptualisasi (pembentukan dan formulasi) strategi, dimana proses implementasi strategi secara utama adalah proses operasional. Dalam hal ini maka proses perkembangan strategi adalah: (a) Proses yang melibatkan sejumlah kecil manajer senior dalam perusahaan, (b) Proses yang lebih cenderung merupakan proses yanng memiliki kadar intelektualitas tinggi yang menuntut tingkat intuisi dan kapabilitas analisa yang tinggi pula, terutama pada tingkatan sintesis, (c) Proses 
yang difokuskan terutama untuk masalah efektivitas alternatif strategi yang dikemukakan sebelumnya (apakah hal ini mampu untuk mencapai tujuan jangka panjang atau tidak bagi perusahaan) dan, (d) Proses yang menggunakan alat serta teknik yang sama bagi seluruh jenis maupun ukuran perusahan, dan (e) Proses yang hanya mendistribusikan sumber daya strategis ke seluruh lini perusahaan.

Sebaliknya, proses implementasi strategis adalah: (a) Proses yang melibatkan koordinasi dari berbagai kelompok pegawai yang berbeda dalam perusahaan dan juga berbagai individu yang berbeda dalam perusahaan, (b) Proses yang dilibatkan dengan keseharian bisnis dan terutama menuntut kapabilitas kepemimpinan yang berguna untuk menimbulkan motivasi bagi seluruh sumber daya dalam perusahaan, (c) Proses yang difokuskan utamanya pada efisiensi (peningkatan produktivitas dan tingkat profitabilitas dari masing-masing departemen, divisi, unit bisnis strategis (Strategic Business Unit atau SBU), dan seluruh perusahaan) terhadap strategi yang diimplementasikan, (c) Proses yang menggunakan alat dan teknik yang berbeda untuk berbagai jenis dan ukuran perusahaan yang berbeda pula, dan (d) Perusahaan yang mencoba untuk mengelola dan mengatur secra efisien sumber daya strategis dan sumber daya non strategis dalam masing-masing unit produktif dan unit non produktif yang terpisah dalam perusahaan dimana cara semacam ini digunakan utnuk mencapai tujuan jangka pendek tahunan yang lebih terspesifikasi.

Ini adalah alasan lainnya mengapa proses implementasi strategi secara utama lebih menggunakan informasi finansial untuk pengukuran kinerja tahunan dari masing-masing unit terpisah dalam perusahaan, dan utamanya lebih menggunakan sistem pengendali tradisional (sistem biaya, sistem penganggaran, alat ukur finansial dari kinerja jangka pendek, dan lain sebagainya). Terdapat banyak bukti empiris yang membuktikan penegasan ini di berbagai negara, termasuk Indonesia (Henri, 2006).

Secara umum, responden dalam penelitian ini memberikan indikasi bahwa proses perkembangan strategi dan proses implementasi strategi akan dibedakan dan kedua proses ini relatif lebih terstruktur dan resmi. Proses strategis direncanakan dan dijelaskan sehingga tidak ada indikasi yang menunjukkan adanya proses yang bersifat spontan ataupun mendadak yang membentuk proses perkembangan dan implementasi strategi. Hal ini memberikan dukungan pada H1. Beberapa keputusan strategis berkaitan dengan rencana perusahaan yang melekat erat pada siklus perencanaan tahunan yang memainkan peranan penting dalam perkembangan unit bisnis strategis pada perusahaan tersebut.

\section{DAFTAR RUJUKAN}

Amit, R., Schoemaker, P.J.H. (1993) "Strategic assets and organizational rent", Strategic Management Journal, 14 (1), 33-46.

Bhimani, A., Keshtvarz, M.A., (1999) "British management accountants: strategically oriented", Journal of Cost Management, (Spring), 25-31.

Bhimani, A., Langfield-Smith, K., (2007) "Structure, formality and the importance of financial and non-financial information in strategy development and implementation", Management Accounting Research, 18 (1), 3-31.

Boyd, B.K., E. Reuning-Elliott (1998) "A measurement Model of Strategic Planning”, Strategic Management Journal, 19 (2), 181-192.

Brecková, P. and Havlícek, K., (2013) "Leaders Management and Personnel Controlling in SMEs", European Research Studies Journal, XVI, (4), 3-14. 
Brouthers, K.D., Roozen, F.A., (1999) "Is it time to start thinking about strategic accounting?" Long Range Planning, 32 (3), pp. 311-322.

Bushman, M. (2007) "An overview on Management Accounting”, Business and Finance, $12,1-17$.

Chenhall, R., (2005) "Content and process approaches to studying strategy and management control systems", Controlling Strategy: Management, Accounting, and Performance Measurement, Oxford University Press, Oxford.

Chenhall,R., Langfield-Smith, K., (1998) "Adoption and benefits of management accounting practices: An Australian study", Management Accounting Research, 9, 119.

David, F. R., (2010) "Strategic M anagement" 13/e, Prentice Hall, London.

Glaister, K.W., O. Dincer, E. Tagoglu, M. Demirbag, and S.Zaim (2008) "A casual analysis of formal strategic planning and firm performance: Evidence from an emerging country", Management Decision, 46 (3), 365 - 391.

Goold, M., Quinn, J.J., (1990) "The paradox of strategic controls", Strategic Management Journal, 11, 43-57.

Grant, R.M., (1996) "Toward a knowledge-based theory of the firm", Strategic Management Journal, 17 (2), 153-174.

Guilding, C., Cravens, K.S., and Tayles, M., (2000) "An international comparison of strategic management accounting practices", Management Accounting Research, 11 (1), 113-135.

Guilding, C., McManus, L., (2002) "The incidence, perceived merit and antecedents of customer accounting: an exploratory note", Accounting, Organization and Society, 27 (1/2), 45-59.

Hamel G., Prahalad, C.K., (1994) "Competing for the future", Harvard Business School Press: Boston.

Havlícek, K., Brecková, P. and Zampeta, V., (2013) "Quality Management as a Part of CRM", European Research Studies Journal, XVI, (4) 15-28.

Henri, J. F., (2006) "Management control systems and strategy: A resource-based perspective", Review, Accounting, Organization and Society, 31, 529-558.

Hunt, S. (1990) "Commentary on an Empirical Investigation of a General Theory of Marketing Ethics", Journal of the Academy of Marketing Science, 18 (2), 173-177.

Ismail, Tubagus (2016) "Culture control, capability and performance: Evidence from creative industries in Indonesia". Asian Review of Accounting. 24 (2), 171-184.

Ismail, Tubagus and Ghozali, Imam (2015) "Control system, strategy and learning". Academy of Strategic Management Journal 14 (1), 58.

Kaplan, R.S., Norton, D.P., (2004) "Strategy Maps: Converting Intangible Assets into Tangible Outcomes", Harvard Business School: Boston, MA.

Mintzberg, H., and McHugh, A., (1995) "Strategy formation in an adhocracy", Administrative Science Quarterly, 30, 160-197.

Palmer, R.J., (1992) "Strategic goals and objectives and the design of strategic management accounting systems", Advances in Management Accounting, (1), 179206.

Poincelot, E., G. Wegmann (2006) "Prescriptives of non financial indicators as a strategicmanagement tool", Working Papers FARGO 1060905, Université de BourgogneLatec/Fargo (Research center in Finance, organizational Architecture and Governance): http://ideas.repec.org/e/pwe108.html. 
Porter, M., (1985) "Competitive Advantage: Creating and Sustaining SuperiorPerformance", Free Press, New York.

Porter, M., (2001) "Strategy and the Internet", Harvard Business Review, 101 (2), 63-78.

Quinn, J.B., (1980) "Strategy for Change: Logical Incrementalism", Irwin: Homewood, IL.

Roslender, R., (1996) "Accounting for strategic positioning: responding to the crisis in management accounting”, British Journal of Management, 6, 45-57.

Saunders, M., Lewis and P., Thornhill, A. (2000) "Research Methods for Business Students", 2 nd edition, Pearson Education: London.

Schoemaker, P.J.H., Amit, R.H., (1994) "Investment in strategic assets: industry and firmlevel perspectives", Advances in Strategic Management, vol. 10, JAI Press: Greenwich,CT, pp. 3-33.

Shank, J.K., (1996) "New wines in old bottles: Reichard Maschinen GmbH", Journal ofCost Management, (Summer), 49-59.

Shank, J.K., Govindarajan, V., (1992) "Strategic cost management: the value chainperspective", Journal of Management Accounting Research, 4 (Fall), 179-197.

Simmonds, K., (1982), "Strategic management accounting", Management Accounting, CIMA (April), 26-29.

Thalassinos, E. Havlícek, K and Berezkinova, L., (2013) "Innovation Management andControlling in SMEs", European Research Studies Journal, XVI, (4), 57-70.

West, S. G., Finch, J. F., and Curran, P. J. (1995) "Structural equation models with nonnormal variables: Problems and remedies", Structural equation modeling: Concepts, issues, and applications, Sage: Thousand Oaks, CA, pp. 56-75.

Widener, S.K. (2006) "Associations between strategic resource importance and performance measure use: The impact in firm performance", Management Accounting Research, 17, 433-457.

Zikmund, W.G. (2003) "Business research methods", 7th edition, Thomson, SouthWestern, Mason. 


\section{Lampiran}

Tabel A1. Formal struktur proses manajemen strategi

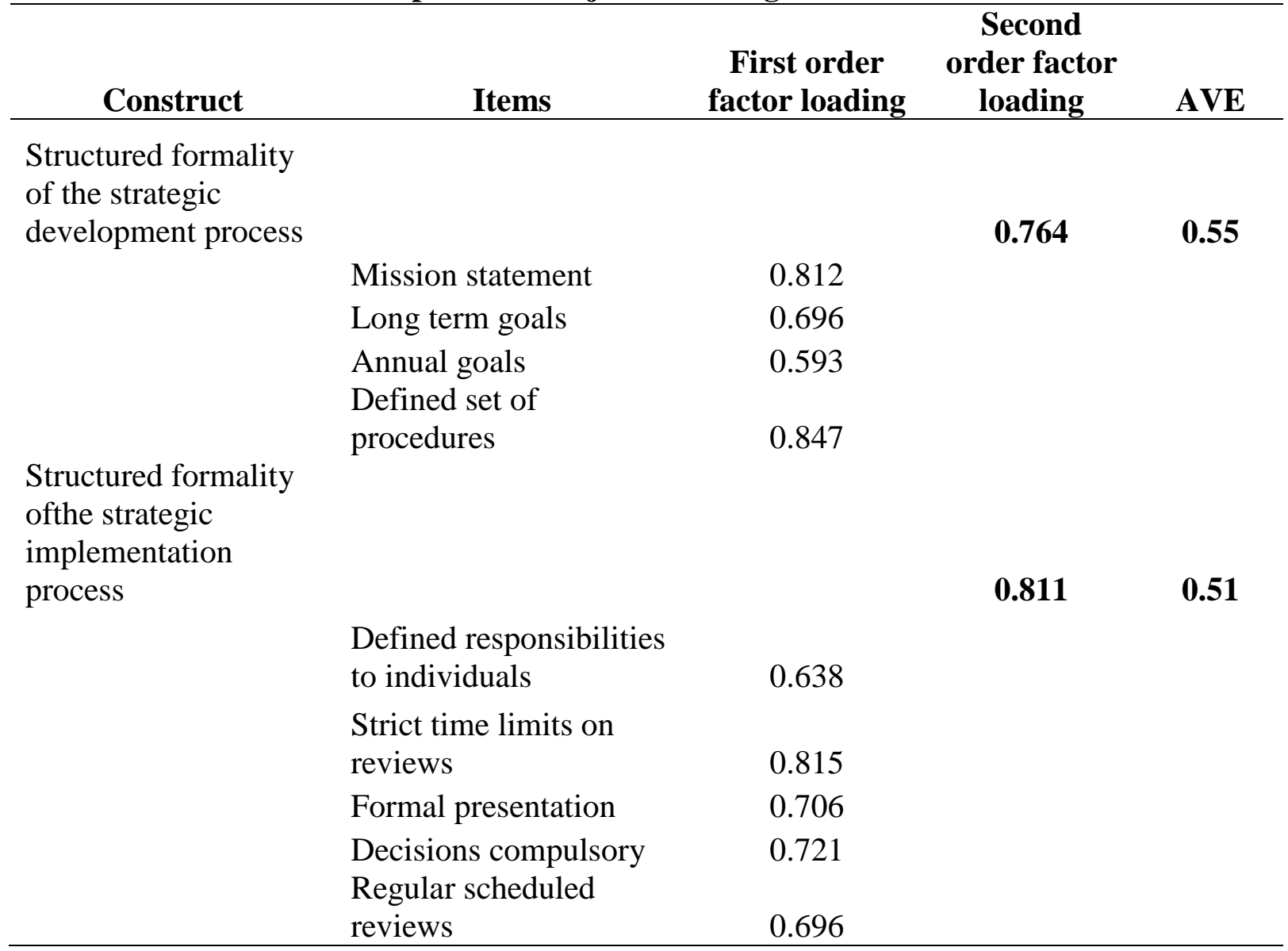


Tabel A2. Pentingnya informasi keuangan dan non keuangan pada proses pengembangan strategi

\begin{tabular}{|c|c|c|c|c|}
\hline Construct & Items & $\begin{array}{c}\text { First order } \\
\text { factor } \\
\text { loading }\end{array}$ & $\begin{array}{c}\text { Second } \\
\text { order } \\
\text { factor } \\
\text { loading }\end{array}$ & AVE \\
\hline \multirow[t]{6}{*}{$\begin{array}{l}\text { Importance of financial } \\
\text { information }\end{array}$} & & & 0.846 & 0.58 \\
\hline & Profit & 0.746 & & \\
\hline & ROI & 0.779 & & \\
\hline & Sales & 0.841 & & \\
\hline & ROA & 0.663 & & \\
\hline & Financial targets & 0.785 & & \\
\hline \multirow[t]{9}{*}{$\begin{array}{l}\text { Importance of non } \\
\text { financial information }\end{array}$} & & & 0.893 & 0.63 \\
\hline & Public image & 0.787 & & \\
\hline & Employee satisfaction & 0.754 & & \\
\hline & Employee commitment & 0.842 & & \\
\hline & Customer satisfaction & 0.667 & & \\
\hline & Competitor comparison & 0.889 & & \\
\hline & Product quality & 0.858 & & \\
\hline & Degree of technology & 0.936 & & \\
\hline & Market share & 0.587 & & \\
\hline
\end{tabular}


Tabel A3. Pentingnya informasi keuangan dan non keuangan pada proses implementasi

\begin{tabular}{|c|c|c|c|c|}
\hline Construct & Items & $\begin{array}{c}\text { First order } \\
\text { factor } \\
\text { loading }\end{array}$ & $\begin{array}{c}\text { Second } \\
\text { order } \\
\text { factor } \\
\text { loading }\end{array}$ & AVE \\
\hline \multirow[t]{6}{*}{$\begin{array}{l}\text { Importance of financial } \\
\text { information }\end{array}$} & & & 0.991 & 0.57 \\
\hline & Profit & 0.724 & & \\
\hline & ROI & 0.756 & & \\
\hline & Sales & 0.858 & & \\
\hline & ROA & 0.68 & & \\
\hline & Financial targets & 0.822 & & \\
\hline \multirow[t]{9}{*}{$\begin{array}{l}\text { Importance of non } \\
\text { financial information }\end{array}$} & & & 0.923 & 0.61 \\
\hline & Public image & 0.731 & & \\
\hline & Employee satisfaction & 0.783 & & \\
\hline & Employee commitment & 0.819 & & \\
\hline & Customer satisfaction & 0.727 & & \\
\hline & Competitor comparison & 0.905 & & \\
\hline & Product quality & 0.813 & & \\
\hline & Degree of technology & 0.851 & & \\
\hline & Market share & 0.614 & & \\
\hline
\end{tabular}

Tabel A4. Indek model fit

\begin{tabular}{lcccc} 
Indices & Cut-off & $\begin{array}{c}\text { Structured formality } \\
\text { of the strategic } \\
\text { management process }\end{array}$ & $\begin{array}{c}\text { Importance of } \\
\text { financial and non } \\
\text { financial information } \\
\text { for SD }\end{array}$ & $\begin{array}{c}\text { Importance of } \\
\text { financial and non } \\
\text { financial } \\
\text { information for } \\
\text { impl }\end{array}$ \\
\hline Chi Square & ----- & 67.6 & 14.72 & 160.23 \\
P Value & $>0.05$ & 0.005 & 0 & 0.003 \\
d.f & ----- & 26 & 64 & 64 \\
GFI & 0.9 & 0.93 & 0.91 & 0.92 \\
AGFI & 0.83 & 0.88 & 0.87 & 0.86 \\
RMSEA & $<0.08$ & 0.054 & 0.079 & 0.075 \\
CFI & $>0.90$ & 0.93 & 0.92 & 0.93 \\
\hline
\end{tabular}


Tabel 5. Composite reliability

\begin{tabular}{lc}
\hline Factor & $\begin{array}{c}\text { Composite } \\
\text { reliability }\end{array}$ \\
\hline Structured formality of strategy development process & 0.83 \\
Structured formality of strategy implementation process & 0.84 \\
Financial information for strategy development process & 0.875 \\
Non Financial information for strategy development process & 0.929 \\
Financial Information for strategy implementation process & 0.842 \\
Non Financial Information for strategy implementation process & 0.925 \\
\hline
\end{tabular}

Tabel 6. Discriminant validity test

\begin{tabular}{lcrrrrr}
\hline Factor & 1 & 2 & 3 & 4 & 5 & 6 \\
\hline Structured formal development & 0.742 & & & & & \\
Structured formal implementation & 0.159 & 0.714 & & & & \\
$\begin{array}{l}\text { Financial for strategy development } \\
\text { Financial for strategy implementation }\end{array}$ & 0.064 & 0.098 & 0.716 & & & \\
& 0.142 & 0.141 & 0.661 & 0.754 & & \\
Non Financial for strategy development & 0.04 & 0.065 & 0.024 & 0.061 & 0.794 & \\
$\begin{array}{l}\text { Non Financial for strategy } \\
\text { implementation }\end{array}$ & 0.38 & 0.425 & 0.004 & 0.163 & 0.165 & 0.781 \\
\hline
\end{tabular}

